\title{
Penggunaan Bahasa Indonesia pada Ruang Publik di Kota Gorontalo
}

\author{
Armiati Rasyid \\ Kantor Bahasa Gorontalo \\ Jalan Dokter Zainal Umar Sidiki, Tunggulo, Tilongkabila, Bonebolango \\ armiati.rasyid@kemdikbud.go.id
}

\begin{abstract}
Abstrak
Tulisan ini bertujuan mendeskripsikan keterkendalian penggunaan bahasa Indonesia dan bentuk kesalahan penggunaan bahasa Indonesia pada ruang publik di Kota Gorontalo. Kajian ini bersifat kuantitatif. Data dikumpulkan dengan cara observasi dan dokumentasi serta dianalisis dengan teknik persentase. Kajian ini menemukan keterkendalian penggunaan bahasa ruang publik di Kota Gorontalo berada pada kategori Terkendali $C$ (wilayah yang penggunaan bahasa di ruang publik kurang terkendali: secara fisik kurang didominasi bahasa asing; mulai lebih banyak berbahasa Indonesia dengan penerapan kaidah dan tipografi yang mulai baik). Hal tersebut dapat dilihat pada aspek kebahasaan yang belum sepenuhnya mengutamakan penggunaan bahasa Indonesia karena memiliki masalah pada ejaan, pilihan kata, dan struktur kalimat. Berdasarkan aspek fisik kebahasaan,posisi, ukuran, dan warna huruf pun belum maksimal mendukungpengutamaan bahasa Indonesia.masih terdapat data yang menempatkan bahasa Indonesia sejajar/bersanding dengan posisi di bawah atau di atas bahasa asing atau bahasa daerah.Sementara itu, berdasarkah aspek tipografi kebahasaannya, bahan, desain, dankejelasan hurufnya sudah proporsional.
\end{abstract}

Kata kunci: ruang publik, aspek kebahasaan, aspek fisik kebahasaan, aspek tipografi kebahasaan, terkendali

\section{Use of Indonesia in Public Space in The City of Gorontalo.}

\begin{abstract}
This paper aims to describe the control of the use of Indonesian and the forms of misuse of Indonesian In Public spaces in Gorontalo City. This study is quantitative. Data collected by observation and documentation and analyzed by percentage techniques. This study found that the control over the use of public space languages in Gorontalo City was in the Controlled C category (areas where the use of language in public spaces was less controlled: physically less dominated by foreign languages; started to speak more Indonesian with the application of rules and typography that began well). This can be seen in the linguistic aspects that have not fully prioritized the use of Indonesian because they have problems with spelling, choice of words, and sentence structure. Based on the physical aspects of language, position, size, and color of letters are not yet optimally support the priority of Indonesian language. There are still data that place Indonesian in line with / position below or above a foreign language or regional language. Meanwhile, based on the typographic aspects of the language, the material, design, and clarity of the letters are proportional.
\end{abstract}

Keywords: public space, linguistic aspects, physical aspects of linguistics, typographic aspects of language, controlled

\section{PENDAHULUAN}

Pesona bahasa asing pada ruang publik seperti di spanduk/kain rentang, baliho, reklame, nama toko, nama perumahan, nama instansi pemerintah dan swasta, dll. merupakan fenomena kebahasaan yang tidak dapat dihindari. Keberadaannya semakin menggerus posisi bahasa Indonesia. Bahkan, menurut Purba dan Suyadi (2016: 11 dan 16) wilayah penggunaan bahasa Indonesia di ruang publik tergeser oleh penggunaan bahasa asing, terutama bahasa Inggris merupakan dampak dari ketidaksiapan mental masyarakat Indonesia dalam menghadapi perdagangan bebas dunia. Penggunaan bahasa asing tersebut mengubah karakter masyarakat Indonesia menjadi rapuh. Masyarakat Indonesia tidak memiliki keteguhan dan pendirian yang kuat, tidak 
memiliki positif terhadap bahasa Indonesia sehingga dengan mudah mengabaikan kaidah bahasa Indonesia dan menghilangkan identitas kebangsaannya.

Hal tersebut pun terjadi di Gorontalo. Sebagai ibu kota provinsi yang berkembang cukup pesat dalam sepuluh tahun terakhir, Kota Gorontalo mengalami perubahan perkembangan perekonomian yang ditandai dengan mulai munculnya pusat perbelanjaan modern, seperti Santika Departement Store, Makro Departement Store, Mall Mega Zanur, Karsa Utama Mall, Gorontalo Bussiness Center, Gorontalo Mall yang sekarang berubah menjadi Citimall Gorontalo, dan menjamurnya pasar swalayan mini seperti Alfa Mart, Indomart, sertabeberapa kafe dan restoran.

Sejalan dengan itu, di bidang pariwisata pun demikian,terdapat taman hiburan Planet Waterboom, di bidang perhotelan terdapat Grand Q Hotel, Imperial Hotel, Maqna Hotel, New Horison Hotel, Eljie Hotel Syariah, Mega Zanur Hotel, Millinov Boutique Hotel, The Garden Hotel, dan Guest House, bidang kuliner muncul Coffee Toffee Kingdom of Food, Istana Cokelat Bakery, Extra Bakery, Olivia Resto \& Bakery Gorontalo, dan lain-lain.

Jika ditinjau dari segi pemartabatan bahasa Indonesia, fakta di atas membuktikan bahwa bahasa Indonesia semakin tergerus oleh pesona bahasa asing yang tidak mampu ditolak oleh masyarakat. Kondisi kebahasaan tersebut di atas tentu saja sangat bertentangan dengan amanah UUD 1945 Pasal 36 dan Undang-Undang No. 24 Tahun 2009 tentang Bendera, Bahasa, dan Lagu Kebangsaan.

Sehubungan dengan itu, tulisan ini akan mengkaji penggunaan bahasa Indonesia pada ruang publik di Kota Gorontalo.

Kajian seperti ini telah dilakukan oleh peneliti sebelumnya. Misalnya yang dilakukan oleh Rosadi (2017) tentang penggunaan ejaan pada media luar ruang di Kabupaten Gorontalo Utara. Rosadi menemukan bahwa pemakaian bahasa Indonesia pada media luar ruang terbagi ke dalam beberapa kategori kesalahan, di antaranya kesalahan penulisan tanda baca (tanda titik, tanda koma, tanda titik dua, tanda hubung, tanda pisah) kesalahan penulisan huruf, dan kesalahan penulisan kata (kata depan, kata turunan, angka dan lambang bilangan, gabungan kata).

Hal serupa juga pernah dilakukan oleh Cahyo Hasanuddin pada tahun 2015. Cahyo menulis tentang "Analisis Kesalahan Berbahasa pada Penulisan Media Luar Ruang di Kabupaten Bojonegoro". Dia menemukan bahwa pertama, kesalahan pada aspek pemakaian tanda baca, khususnya tanda titik (.), penulisan kata depan di, penggunaan kata pukul dan jam, dan singkatan. Kedua, jenis kesalahan pemakaian istilah asing didominasi dengan penggunaan bahasa Inggris dan bahasa Jawa.

Dalam penelitian lain, Ercita Intan Nurkumala, dkk. (2015) juga meneliti tentang "Penggunaan Bahasa pada Penulisan Media Luar Ruang di Kota Ketapang". Dalam penelitian tersebut, mereka menyimpulkan bahwa Kota Ketapang termasuk ke dalam wilayah terkendali 3, yaitu wilayah yang penggunaan bahasa asingnya cukup terkendali, dengan lebih mengutamakan penggunaan bahasa Indonesia atau pelestarian bahasa daerah.

Hal senada jug dilakukan oleh Kurniawati (2015: 177). Dalam penelitiannya, dia mengemukakan bahwa data yang sesuai dengan kaidah berjumlah 40 buah $(56,3 \%)$ dan data yang tidak sesuai dengan kaidah sebanyak 31 buah $(43,7 \%)$. Dengan demikian, frekuensi data yang sesuai dengan kaidah lebih dominan daripada data yang tidak sesuai dengan kaidah atau dengan kata lain, penyusun bahasa dalam media luar ruang dapat dikatakan memiliki sikap positif terhadap bahasa Indonesia.

Berdasarkan beberapa hasil penelitian tersebut, kajian ini berfokus pada keterkendalian penggunaan bahasa Indonesia pada ruang publik dan bentuk kesalahan penggunaan bahasanya. Keberadaan hasil kajian ini diharapkan dapat memperkuat dan mendukung hasil penelitian sebelumnya dan sebagai bahan 
pertimbangan pemerintah dalam memberikan perhatian khusus terhadap pemartabatan bahasa Indonesia pada ruang publik dengan memberlakukan peraturan penggunaan bahasa Indonesia di segala lini.

\section{TEORI}

\section{Undang-Undang No. 24 Tahun 2009}

Penggunaan bahasa Indonesia diatur dalam Undang-Undang No. 24 Tahun 2009 khususnya yang mengatur tentang pengutamaan bahasa negara di ruang publik.Aturan tersebut tertuang pada Pasal 36-38. Pasal 36 mengatur tentang penggunaan bahasa Indonesia wajib digunakan dalam nama geografi di Indonesia; nama bangunan atau gedung, jalan, apartemen atau permukiman, perkantoran, kompleks perdagangan, merek dagang, lembaga usaha, lembaga pendidikan, organisasi yang didirikan atau dimiliki oleh warga negara Indonesia atau badan hukum Indonesia. Selanjutnya, Pasal 37 mengatur tentang penggunaan bahasa Indonesia wajib digunakan dalam informasi produk barang atau jasa produksi dalam negeri atau luar negeri yang beredar di Indonesia.Kemudian, Pasal 38 mengatur tentang penggunaan bahasa Indonesia pada rambu umum, penunjuk jalan, fasilitas umum, spanduk, dan alat informasi lainnya yang merupakan pelayanan umum.

\section{Keterkendalian Penggunaan Bahasa Ruang Publik}

Dalam Petunjuk Teknis Pengutamaan Bahasa Negara di Ruang Publik (Tim Penyusun, 2018: 10--13), dijelaskan bahwa keterkendalian bahasa ruang publik dapat dilihat pada tiga aspek kondisi pengutamaan bahasa Indonesia di ruang publik yaitu bentuk fisik kebahasaan, penggunaan kaidah kebahasaan, dan tipografi kebahasaan. Setiap aspek tersebut memiliki indikator yang menjadi bahan pertimbangan dalam penilaian keterkendalian dan dilengkapi dengan skor sesuai dengan kriteria data, seperti pada instrumen yang digunakan dalam kajian ini. 


\begin{tabular}{|c|c|c|}
\hline \multicolumn{3}{|c|}{$\begin{array}{l}\text { Tabel 1. Instrumen Penilaian Data Kajian Penggunaan Bahasa Indonesia } \\
\text { pada Ruang Publik di Kota Gorontalo }\end{array}$} \\
\hline Variabel & Skor & Kriteria \\
\hline \multicolumn{3}{|r|}{ Fisik Kebahasaan } \\
\hline \multirow{4}{*}{ Posisi } & 30 & Hanya menempatkan bahasa negara \\
\hline & 20 & $\begin{array}{l}\text { Menempatkan bahasa negara di atas/di bawah/ berdampingan } \\
\text { dengan bahasa asing dan/atau bahasa tak resmi }\end{array}$ \\
\hline & 10 & $\begin{array}{l}\text { Hanya menempatkan bahasa asing dan/atau bahasa tak resmi } \\
\text { (kedaerahan) }\end{array}$ \\
\hline & 30 & $\begin{array}{l}\text { Menggunakan bahasa negara saja (dalam ukuran apa pun) ukuran } \\
\text { bahasa negara lebih besar daripada bahasa asing dan/atau bahasa tak } \\
\text { resmi (kedaerahan) }\end{array}$ \\
\hline \multirow[t]{3}{*}{ Ukuran huruf } & 20 & $\begin{array}{l}\text { Membuat ukuran huruf bahasa negara sama dengan bahasa asing } \\
\text { dan/atau bahasa tak resmi (kedaerahan) }\end{array}$ \\
\hline & 10 & $\begin{array}{l}\text { Membuat ukuran huruf bahasa negara sama lebih kecil daripada } \\
\text { bahasa asing dan/atau bahasa tak resmi (kedaerahan); hanya } \\
\text { menggunakan bahasa asing dan/atau bahasa tak resmi (kedaerahan) } \\
\text { dalam ukuran apa pun }\end{array}$ \\
\hline & 30 & $\begin{array}{l}\text { Menggunakan bahasa negara saja (dalam warna apa pun) warna } \\
\text { bahasa negara lebih menonjol daripada bahasa asing dan/atau } \\
\text { bahasa tak resmi (kedaerahan) }\end{array}$ \\
\hline \multirow[t]{2}{*}{ Warna huruf } & 20 & $\begin{array}{l}\text { Membuat warna huruf bahasa negara sama dengan bahasa asing } \\
\text { dan/atau bahasa tak resmi (kedaerahan) }\end{array}$ \\
\hline & 10 & $\begin{array}{l}\text { Membuat warna bahasa asing lebih mencolok daripada bahasa } \\
\text { negara atau hanya menggunakan bahasa asing dan/atau bahasa tak } \\
\text { resmi (kedaerahan) }\end{array}$ \\
\hline
\end{tabular}

\begin{tabular}{|c|c|c|}
\hline Variabel & Skor & Kriteria \\
\hline \multicolumn{3}{|r|}{ Kaidah Kebahasaan } \\
\hline & 30 & $\begin{array}{l}\text { Tidak terdapat kesalahan dalam pemakaian huruf, penulisan kata, } \\
\text { pemakaian tanda baca, dan penulisan unsur asing/serapan }\end{array}$ \\
\hline Ejaan & 20 & $\begin{array}{l}\text { Terdapat satu atau dua kesalahan dalam pemakaian huruf, penulisan } \\
\text { kata, pemakaian tanda baca, dan penulisan unsur asing/serapan } \\
\text { Terdapat lebih dari dua kesalahan dalam pemakaian huruf, penulisan } \\
\text { kata, pemakaian tanda baca, dan penulisan unsur asing/serapan; } \\
\text { hanya menggunakan sistem ejaan bahasa asing dan/atau bahasa tak } \\
\text { resmi (kedaerahan) }\end{array}$ \\
\hline \multirow{3}{*}{ Pilihan Kata } & 30 & $\begin{array}{l}\text { Tidak terdapat kesalahan dalam pemilihan kata (tepat, benar, dan } \\
\text { lazim) untuk bahasa Negara }\end{array}$ \\
\hline & 20 & $\begin{array}{l}\text { Terdapat kesalahan dalam pemilihan kata (tepat, benar, dan lazim) } \\
\text { untuk bahasa Negara }\end{array}$ \\
\hline & 10 & $\begin{array}{l}\text { Hanya menggunakan pilihan kata asing/bahasa tak resmi } \\
\text { (kedaerahan) }\end{array}$ \\
\hline Struktur & $\begin{array}{l}30 \\
20\end{array}$ & $\begin{array}{l}\text { Tidak terdapat kesalahan struktur dalam penyusunan frasa/kalimat } \\
\text { (termasuk yang hanya menggunakan satu kata) bahasa negara } \\
\text { Terdapat kesalahan struktur dalam penyusunan frasa/kalimat bahasa } \\
\text { Negara }\end{array}$ \\
\hline
\end{tabular}


Armiati Rasyid: Penggunaan Bahasa Indonesia pada Ruang Publik di Kota Gorontalo

\begin{tabular}{|c|c|l|}
\multicolumn{2}{|c|}{10} & $\begin{array}{l}\text { Hanya menggunakan struktur bahasa asing/bahasa tak resmi } \\
\text { (kedaerahan) }\end{array}$ \\
\hline \multirow{3}{*}{ Bahan } & 30 & \multicolumn{1}{|c|}{ Tipografi Kebahasaan } \\
& 20 & Terbuat dari bahan permanen (kayu, batu, kaca, atau kaca serat) \\
& 10 & Terbuat dari bahan semipermanen (plastik, kain, atau styrofoam) \\
& 30 & Terlihat desain yang sangat menarik \\
& 20 & Terlihat desain yang cukup menarik \\
& 10 & Terlihat desain yang tidak menarik \\
& 30 & Terlihat tulisan yang sangat jelas dan proporsional \\
Kejelasan & 20 & Terlihat tulisan yang kurang jelas dan kurang proporsional \\
& 10 & Terlihat tulisan yang tidak jelas dan tidak proporsional \\
\hline
\end{tabular}

\section{Penggunaan Nama Indonesia bagi Badan Usaha, Kawasan, dan Bangunan}

Penamaan sebuah tempat usaha, kawasan, bangunan, gedung sebaiknya mengikuti struktur penamaan dalam bahasa Indonesia berikut. (Tim Penyusun Pengindonesiaan Kata dan Ungkapan Asing, 2012: 6-8)

1. Nama badan usaha, kawasan, dan bangunan dapat diambil dari nama diri (misalnya Wijaya, Gunung Muria) atau kata umum (misalnya Indah Abadi, Sumber Agung), atau gabungan keduanya (misalnya, Sanjaya Cemerlng, Semarang Sakti)

2. Istilah juga dapat menjadi bagian nama badan usaha, kawasan, dan bangunan untuk mempertegas identitas, misalnya Bank Devisa Deli dan Kawasan Industri Mitra Usaha.

3. Jika badan usaha, kawasan, dan bangunan menggunakan baik nama Indonesia maupun nama asing, nama Indonesia ditempatkan di atas nama asing itu. Misalnya:

\section{Balai Sidang Jakarta} Jakarta Convention Center

4. Nama asing yang digunakan untuk badan usaha, kawasan, dan bangunan perlu dilengkapi dengan padanannya dalam bahasa Indonesia, misalnya

Tepian Danau Bogor

Bogor Lakeside
5. Nama asing badan usaha yang merupakan cabang luar negeri dan nama asing merek dagang yang terdaftar dan memiliki hak paten tetap dipakai, misalnya:

Citibank, Goodyear, Gucci, Kentucky

Fried Chicken, Mitsubishi.

6. Sumber pertama untuk nama badan usaha, kawasan, dan bangunan ialah bahasa Indonesia. Misalnya kata gedung, kawasan, menara, perumahan, taman. Sumber kedua ialah bahasa daerah, misalnya asri, gria, saung, tirta, pondok. Sumber ketiga ialah bahasa asing yang sulit dicari padanannya dalam bahasa Indonesia atau bahasa daerah atau yang bentuknya lebih ringkas daripada terjemahannya, misalnya apartemen, bazar, hotel, mal, plaza, vila.

\section{Cara Pembentukan Nama}

Adapun tata cara pembentukan nama badan usaha, kawasan, dan bangunan sebagai berikut (Tim Penyusun Pengindonesiaan Kata dan Ungkapan Asing, 2012: 8-10).

1. Kata yang menjadi bagian nama badan usaha, kawasan, dan bangunan adalah kata yang ringkas dan bernilai rasa yang baik, misalnya Perumahan Pondok Cipta, Kebun Raya Bogor

2. Pemilihan bentuk kata dalam pemberian nama didasarkan pada pola pertalian bentuk dengan maknanya, misalnya 
membangun

pembangunan

bangunan

3. Pola "diterangkan-menerangkan" adalah urutan lazim pada kelompok kata.

\section{METODE}

Kajian ini dilakukan dengan pendekatan kuantitatif deskriptif. Data yang dianalisis adalah data tertulis. Sumber data kajian ini berupa berbagai informasi media ruang publik berupa papan nama instansi dan swasta, papan nama pusat dan tempat usaha perdagangan, iklan luar ruang (spanduk/kain rentang, baliho, reklame), papan nama pemukiman dan penginapan, serta petunjuk lalu lintas dan peristiwa, yang terdapat di Kota Gorontalo.

Data dikumpulkan dengan teknik observasi dan dokumentasi. Teknik observasi dilakukan dengan cara mengamati sekaligus mencatat data di lapangan dengan menggunakan instrumen penilaian pengutamaan penggunaan bahasa di ruang publik yang memuat tiga variabel kaidah kebahasaan, fisik kebahasaan, dan tipografi kebahasaan. Ketiga variabel tersebut didukung oleh beberapa indikator. Variabel kaidah kebahasaan terdiri atas ejaan, pilihan kata, dan struktur.Variable fisik kebahasaan meliputi tiga indikator yaitu posisi penggunaan bahasa, ukuran huruf, dan warna huruf.Variable tipografi kebahasaan meliputi bahan, desain, dan kejelasan tulisan.

Sementara itu, teknik dokumentasi digunakan untuk mengambil gambar ruang publik tersebut.

Data dianalisis dengan teknik persentase dan pembobotan yang langkahlangkahnya sebagai berikut.

\section{Misalnya: Pasar Swalayan Gelaelbukan Gelael}

Supermarket/Gelael Pasar Swalayan

4. Pola "diterangkan-menerangkan" dapat diterapkan pada nama yang menjadi satu kata, misalnya Artagraha, Adikarya, Swakars

(1) Pemberian skor 10, 20, atau 30 pada setiap indikator ruang publik di Kota Gorontalo sesuai dengan kriteria data.

(2) Presentase (P) jumlah skor diperoleh dari hasil jumlah skor setiap indikator dibagi jumlah data $(\mathrm{P}=\mathrm{N} / 100)$, Misalnya jumlah skor 10 pada indikator ejaan $=11$, presentasenya $=11 / 100=$ $11 \%$

(3) Aspek fisik kebahasaan yang terkait dengan posisi bahasa Indonesia, posisi bahasa asing, dan posisi bahasa daerah, lokasi objek (strategis atau tidak strategis), warna huruf, dan ukuran objek (besar atau kecil) dengan bobot $50 \%$;

(4) Aspek bahasa terkait dengan penggunaan ejaan, pemilihan kata, dan penggunaan struktur kalimat dengan bobot $30 \%$.

(5) Tipografi kebahasaan terkait dengan sifat bahan yang digunakan objek (permanen atau tidak permanen), desain, dan kejelasan informasinya dengan bobot $20 \%$.

(6) Nilai akhir penggunaan bahasa di ruang publik diperoleh dari penjumlahan nilai setiap aspek yang telah dikalikan dengan nilai bobot masing-masing.

(7) Hasil akhir kajian kemudian diberikan nilai pemeringkatan keterkendalian bahasa sesuai dengan pedoman penggunaan bahasa ruang publik sebagai berikut. 
Tabel 2. Pemeringkatan Hasil

Kajian Penggunaan Bahasa Indonesia di Ruang Publik

\begin{tabular}{|c|c|c|c|c|c|}
\hline Terkendali & Fisik & Kaidah & Tifografi & $\begin{array}{c}\text { Rentang } \\
\text { Nilai }\end{array}$ & Deskripsi \\
\hline $\begin{array}{c}\mathrm{A} \\
\text { (sangat } \\
\text { terkendali) }\end{array}$ & ++ & ++ & ++ & $\begin{array}{l}2.601- \\
3.000\end{array}$ & $\begin{array}{lcr}\text { secara fisik tidak } & \text { ditemukan } \\
\text { bahasa asing; } & \text { sepenuhnya } \\
\text { berbahasa negara ran dengan } \\
\text { penerapan kaidah dan tipografi } \\
\text { yang sangat baik }\end{array}$ \\
\hline $\begin{array}{c}\mathrm{B} \\
\text { (lebih } \\
\text { terkendali) }\end{array}$ & + & + & + & $\begin{array}{l}2.201- \\
2.600\end{array}$ & $\begin{array}{l}\text { secara fisik tidak didominasi } \\
\text { bahasa asing; lebih banyak } \\
\text { berbahasa negara dengan } \\
\text { penerapan kaidah dan tipografi } \\
\text { yang telah lebih baik }\end{array}$ \\
\hline $\begin{array}{c}\text { C } \\
\text { (cukup } \\
\text { terkendali) }\end{array}$ & - & + & + & $\begin{array}{l}1.800 \\
2.200\end{array}$ & $\begin{array}{l}\text { secara fisik masih didominasi } \\
\text { bahasa asing; masih sedikit } \\
\text { berbahasa negara dengan } \\
\text { penerapan kaidah dan tipografi } \\
\text { yang cukup baik }\end{array}$ \\
\hline $\begin{array}{c}\mathrm{D} \\
\text { (kurang } \\
\text { terkendali) }\end{array}$ & - & - & - & $\begin{array}{l}1.400- \\
1.799\end{array}$ & $\begin{array}{l}\text { secara fisik masih sangat } \\
\text { didominasi bahasa asing; sangat } \\
\text { sedikit berbahasa negara dengan } \\
\text { penerapan kaidah dan tipografi } \\
\text { yang kurang baik }\end{array}$ \\
\hline $\begin{array}{c}\text { E } \\
\text { (sangat } \\
\text { kurang } \\
\text { terkendali) }\end{array}$ & -- & -- & -- & $\begin{array}{l}1.000- \\
1.399\end{array}$ & $\begin{array}{l}\text { secara fisik sangat didominasi } \\
\text { bahasa asing; masih sangat sedikit } \\
\text { berbahasa negara dengan } \\
\text { penerapan kaidah dan tipografi } \\
\text { yang cukup baik. }\end{array}$ \\
\hline
\end{tabular}

Setelah nilai keterkendalian diketahui, data dianalisis kembali dengan mengambarkan setiap kesalahan penggunaan bahasa Indonesianya berdasarkan kaidah ejaan, pilihan kata, dan struktur kalimat.

\section{HASIL DAN PEMBAHASAN Aspek Kebahasaan pada Ruang Publik Kota Gorontalo}

Aspek kebahasaan media ruang publik di Kota Gorontalo sangat memprihatinkan karena pada umumnya tidak mengutamakan bahasa negara. Hal tersebutdapat dilihat pada Grafik 1 berikut.

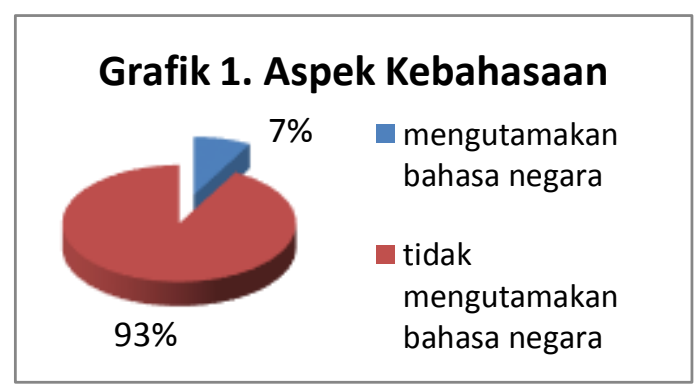

Berdasarkan Grafik 1 di atas, diketahui bahwa dari aspek kebahasaan, hanya 7 data
(7\%) yang mengutamakan penggunaan bahasaIndonesia dan sebanyak $93 \%$ tidak 
mengutamakan bahasa terdapat masalah pada ejaan, pilihan kata, dan struktur kalimat. Dari segi ejaan, dapat dilihat pada Grafik 2 berikut.

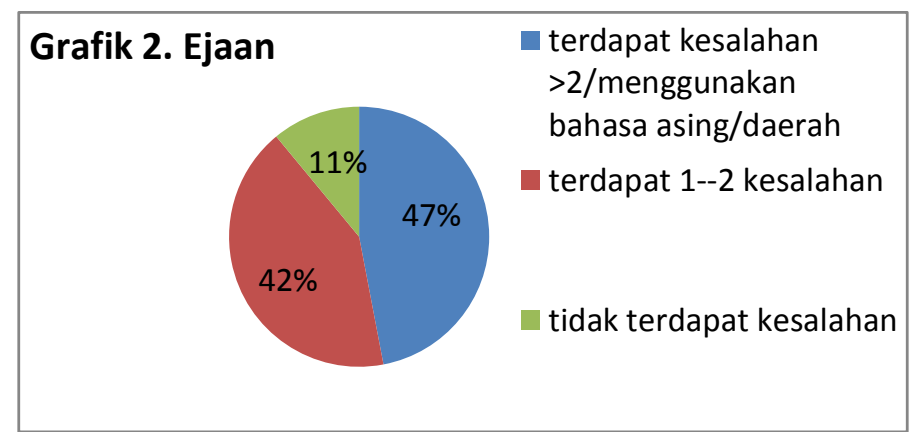

Berdasarkan Grafik 2 tersebut, diketahui bahwa hanya $11 \%$ data yang benar, $42 \%$ karena terdapat kesalahan ejaan paling banyak 2, dan $47 \%$ karena terdapat lebih dari dua kesalahan dalam pemakaian huruf, penulisan kata, pemakaian tanda baca, dan penulisan unsur asing/serapan; hanya menggunakan sistem ejaan bahasa asing dan/atau bahasa tak resmi (kedaerahan). Sementara itu, berdasarkan pilihan kata, dapat dilihat pada Grafik 3 berikut.

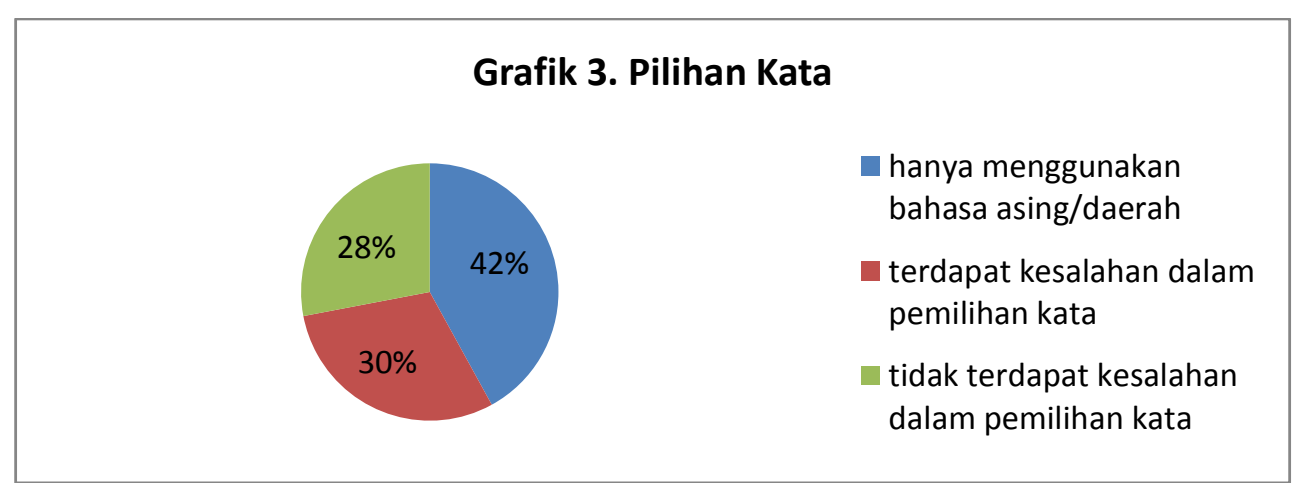

Berdasarkan Grafik 3 di atas, negara, dan $42 \%$ data karena hanya diketahui bahwa dari segi pilihan kata, terdapat $28 \%$ data yang benar, $30 \%$ data menggunakan pilihan kata asing/bahasa tak resmi (kedaerahan). karena terdapat kesalahan dalam pemilihan kata (tepat, benar, dan lazim) untuk bahasa

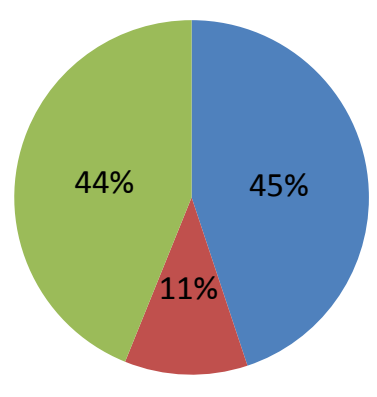

\section{Grafik 4. Struktur kalimat}

- Hanya menggunakan struktur bahasa asing/bahasa tak resmi (kedaerahan)

- Terdapat kesalahan struktur dalam penyusunan frasa/kalimat bahasa negara

- Tidak terdapat kesalahan struktur dalam penyusunan frasa/kalimat (termasuk yang hanya menggunakan satu kata) bahasa negara 
Kemudian, berdasarkan Grafik 4 di atas, diketahui bahwa dari aspek struktur kalimat, terdapat $43 \%$ data yang tidak terdapat kesalahan struktur dalam penyusunan frasa/kalimat (termasuk yang hanya menggunakan satu kata) bahasa negara, $13 \%$ data yang terdapat kesalahan struktur dalam penyusunan frasa/kalimat bahasa negara, dan $44 \%$ data yang hanya menggunakan struktur bahasa asing/bahasa tak resmi (kedaerahan).

\section{Penggunaan Kaidah Kebahasaan pada Ruang Publik di Kota Gorontalo Penggunaan bahasa Indonesia pada nama hotel}

Data nama hotel dalam kajian ini sebanyak sepuluh nama hotel yaitu Grand Zanur Hotel (25-Gto-01), Guest House Hotel (25-Gto-02), Eljie Group Hotel and Travel (25-Gto-03), Krawang City Hotel (25-Gto-04), Hotel Liberty (25-Gto-05), Imperial Hotel (25-Gto-06), New ferrizon Hotel (25-Gto-07), Paradise Hotel (25-Gto08),

Sunrise Hotel (25-Gto-09), Millinov Hotel (25-Gto-10).

Kesepuluh nama hotel tersebut semuanya menggunakan bahasa asing. Pada dasarnya, nama hotel-hotel tersebut ada yang memiliki padanan dalam bahasa Indonesia, misalnya kata grand'adika; raya; agung;

besar; perdana; resmi; puncak; utama; akbar', guest house 'wisma', new 'baru'.

Selain itu, dari segi struktur, penamaan hotel di atas seharusnya dilakukan berdasarkan pola "diterangkanmenerangkan" (DM) yang lazim dalam pengelompokan kata.Dengan demikian, seyogyanya hotel-hotel tersebut dinamai dengan Hotel Zanur Adika, Hotel Zanur Raya, Hotel Zanur Agung, Hotel Wisma, Grup Eljie, Hotel Eljie, Biro Perjalanan Eljie, Kargo Eljie,Hotel Kota Krawang, Hotel Liberty, Hotel Imperial, Hotel Ferryzon Baru, Hotel Paradise, Hotel Sunrise, dan Hotel Butik Millinov.

\section{Penggunaan bahasa Indonesia pada nama gedung dan nama perumahan}

Dalam kajian ini, terdapat 5 nama gedung pertemuan dan 5 nama perumahan, yaitu Grand Palace Convention Center(25Gto-11), Graha Mulia Convention Centre (25-Gto-12), Yiladia Dulohupa (25-Gto13), Grand Sumber Ria Ballroom (25-Gto14), Gorontalo Convention Center (25-Gto15), Perumahan Misfalah Rasaindo (25Gto-16), Puri Manggis (25-Gto-17), Perumahan Mansai Permai I (25-Gto-18), Citra Garden Estate (25-Gto-19), dan Griya Aan Lestari (25-Gto-20).

Pada data tersebut di atas, terdapat 4 nama gedung yang menggunakan bahasa asing dan 1 nama gedung yang menggunakan bahasa daerah. Sementara itu, 1 nama perumahan yang menggunakan bahasa asing dan 4 nama yang menggunakan bahasa Indonesia.

Beberapa kata dan istilah asing dalam data di atas telah dipadankan ke dalam bahasa Indonesia. Kata palace 'istana, mahligai, persada, puri', convention center/ convention hall 'balai sidang, balai konvensi', ballroom 'balai riung', dan garden 'taman'

Dengan demikian, nama gedung dan nama perumahan yang berbahasa asing dapat dipadankan menjadi Balai Sidang Puri Adika, Balai Pertemuan Puri Raya, Balai Sidang Istana Adika, atau Balai Pertemuan Persada Adika, Balai Sidang Graha Mulia, Balai Pertemuan Graha Mulia, Balai Konvensi Graha Mulia, Balai Riung Agung Sumber Ria, Balai Sidang Gorontalo, Balai Pertemuan Gorontalo, atau Pusat Konvensi Gorontal, dan PermukimanTaman Citra.

$$
\text { Selanjutnya, Data 25-Gto-13, }
$$
Yiladia Doluhupa lo Ulipu Hulondalo, menggunakan bahasa Gorontalo. Kata yiladiya bermakna'istana raja', dulohupa 'musyawarah', ulipu 'negeri', dan Hulondalo 'Gorontalo'. Gedung ini dahulu merupakan istana raja dan sekarang dijadikan sebagai tempat bermusyawarah para pemangku adat di Gorontalo. Sekarang, selain digunakan sebagai ruang pertemuan 
Dewan Adat Gorontalo, juga dapat dimanfaatkan oleh masyarakat umum. Karena memiliki nilai sejarah, nama tempat ini mendapatkan pengecualian dalam UU No. 24 Tahun 2009.

\section{Penggunaan bahasa Indonesia pada nama apotek}

Dalam kajian ini terdapat 10 nama yaitu Apotik Mega Farma (25-Gto-21), Apotik Mirah (25-Gto-22), Milana Apotek dan Swalayan Farmasi (25-Gto-23), Apotek Profil II (25-Gto-24), Klinik Pratama de Smile Apotek Piramid Mulia (25-Gto-25), Apotik Permata (25-Gto-26), Apotek Mitra Harapan (25-Gto-27), Apotek Mulia (25Gto-28), Apotek “Junior" (25-Gto-29), dan Apotek Dua Susun (25-Gto-30).

Dalam kajian ini, terdapat dua macam penulisan nama apotek, yaitu apotek dan apotik. Kata apotik merupakan bentuk tidak baku dari apotek.

Dari segi ejaan, penulisan nama Apotek "Junior" tidak tepat. Dalam kaidah ejaan, salah satu fungsi tanda petik (“...”) adalah untuk mengapit istilah ilmiah yang kurang dikenal atau kata yang mempunyai arti khusus. Dengan demikian, penggunaan tanda petik pada kata junior mengakibatkan makna ambigu, yaitu terdapat makna lain yang ingin disampaikan oleh pemilik apotek yang bukan makna sebenarnya.

Selanjutnya, dari segi struktur penulisan nama apotek, terdapat 1 data yang menggunakan struktur bahasa asing, yaitu Data 25-Gto-23, Milana Apotek dan Swalayan Farmasi, atau berstruktur "menerangkan-diterangkan" (MD), yang seharusnya berstruktur "diterangkanmenerangkan" (DM). Oleh karena itu, nama apotek ini seharusnya Apotek dan Swalayan Farmasi Milana.

\section{Penggunaan bahasa Indonesia pada spanduk/iklan}

Dalam kajian ini ditemukan bahwa penulisan spanduk/iklan di Kota Gorontalo masih terpengaruh oleh bahasa asing dan masih terdapat beberapa kesalahan penggunaan bahasa Indonesia baik pada tataran ejaan, diksi, maupun pada struktur kalimat.

Pada Data 25-Gto-31, informasi nama tempat pada spanduk ini menggunakan gabungan bahasa Indonesia dan bahasa asing, Koperasi Gorontalo Car Online. Kata car dan online telah dipadankan ke dalam bahasa Indonesia melalui penerjemahan, mobil dan dalam jaringan (daring), sehingga nama koperasi ini dapat diubah menjadi Koperasi Mobil Daring Gorontalo.

Pada baris kedua pada data tersebut, terdapat istilah official partner yang telah memiliki padanan dalam bahasa Indonesia yaitu mitra resmi.

Selanjutnya, pada Data-Gto-32, terdapat kesalahan ejaan penggunaan tanda baca garis miring pada penulisan singkatan $s / d$, seharusnya ditulis dengan $s . d$. Selain itu, terdapat kesalahan penulisan kata depan $d i$ pada frasa dibawah. Kata depan di- ditulis terpisah dari kata yang diikutinya, sehingga penulisan dibawah seharusnya terpisah, $d i$ bawah.

Dari segi diksi, pada data ini terdapat istilah asing quick wins program dan seat belt yang dicetak dengan huruf tegak. Istilah quick wins program merupakan program nasional Polri yang secara harfiah bermakna program kemenangan yang cepat. Secara konseptual bermakna sebuah aksi kecil yang cepat mendatangkan sebuah kemenangan yang mampu mendorong kemenangan selanjutnya. Program ini dibangun dengan berfokus pada pemekaran rasa percaya diri dan antusiasme. Istilah ini belum memiliki padanan yang tepat dalam bahasa Indonesia sehingga penggunaannya dibolehkan dengan syarat harus mengikuti aturan penulisan bahasa Indonesia. Oleh karena itu, penulisan istilah ini harus dimiringkan Quick Wins Program. Istilah seat belt pun telah memiliki padanan kata yaitu sabuk kursi atau sabuk pengaman.

Dari segi struktur, diksi potensi pada penindakanpelanggaranpotensi bermakna rancu. Oleh karena itu, pada kata potensi harus ditambahkan pemarkah yang 
dan imbuhan ber- sehingga menjadi penindakan pelanggaran yang berpotensi kecelakaan, makna yang diinginkan pun lebih tepat.

Kemudian, masalah kebahasaan pada Data 25-Gto-33 adalah penulisan tanda baca titik pada singkatan lambang mata uang dan setelah angka uang, Serba Rp. 50.000,-. Dalam kaidah ejaan, singkatan lambang mata uang tidak ditandai dengan tanda baca dan tidak ada spasi antara lambang mata uang dan angka rupiah. Penanda sen pada jumlah uang ditandai dengan tanda koma dan nol $(, 00)$. Oleh karena itu, penulisan yang tepat untuk data ini adalah $R p 50.000,00$.

Pada Data 25-Gto-34, masalah kebahasaan yang perlu diperbaiki adalah penggunaan bahasa asing pada nama tempat yang terdapat pada spanduk iklan tersebut, Mitra Electronic Superstore dan kata cash \& kredit. Kata superstore telah memiliki padanan kata yaitu toko raya sehingga nama toko ini dapat diganti dengan Toko Raya Elektronik Mitra. Sementara itu, kata cash pun harus diganti dengan padananya tunai.

Pada Data 25-Gto-35, aspek ejaan yang perlu dibenahi adalah penggunaan tanda titik pada singkatan $\mathrm{HB}$ dan tanda koma untuk mengantarai nama tempat, $\mathrm{Jl}$. Prof. H.B. Yasin No. 365, Kel. Dulalowo, Kec. Kota Tengah, Kota Gorontalo.

Masalah kebahasaan pada Data 25Gto-36 adalah penggunaan tanda baca petik ganda pada nama tempat Rental Mobil "Zukhruf". Tanda baca tersebut tidak perlu digunakan karena tidak memiliki makna lain, Rental Mobil Zukhruf.

Pada Data 25-Gto-37, aspek ejaan yang perlu dibenahi adalah penggunaan tanda koma pada rincian. Misalnya pada rincian ... angkutan antar jemput, sewa umum dan sewa khusus/taksi online..., seharusnya terdapat tanda koma setelah kata sewa umum.Pada bagian bawah spanduk terdapat tulisan Upaya mewujudkan transportasi yang tertib, lancar dan selamat untuk Gorontalo yang unggul, maju dan sejahtera. Dalam tulisan ini, seharusnya tanda koma digunakan setelah kata lancar dan maju sebagai penanda jeda pada rincian. Oleh karena itu, tulisan tersebut dapat diperbaiki seperti berikut ini, Upaya mewujudkan transportasi yang tertib, lancar, dan selamat untuk Gorontalo yang unggul, maju, dan sejahtera.

Dari segi diksi, terdapat kesalahan pemilihan kata himbauan, yang seharusnya imbauan. Demikian halnya kata online, seharusnya yang digunakan adalah padanannya yaitu dalam jaringan atau daring. Dari segi struktur, kalimat pada data ini mengalami kerancuan makna karena ketidakjelasan subjek dan predikat yang diakibatkan oleh tidak adanya tanda koma setelah keterangan di awal kalimat dan tanda titik di akhir kalimat.

Selanjutnya, pada Data 25-Gto-38 tidak terdapat masalah pada ejaan dan struktur kalimat. Akan tetapi, pada aspek diksi terdapat penggunaan bahasa asing yaitu certified company, official website, customer care. Ketiga istilah tersebut telah dipadankan ke dalam bahasa Indonesia certified company 'perusahaan terdaftar', official website 'laman resmi', dan customer care 'peduli pelanggan'.

Pada Data 25-Gto-39, terdapat kesalahan penggunaan ejaan pada penulisan kata terikat antar-, penulisan se-, pada penulisan singkatan sampai dengan dengan. Hal tersebut dapat dilihat pada isi data berikut ini.

SELAMAT DATANG PESERTA
KEJURNAS ATLETIK ANTAR
PPLP/PPLP-
D/SKOSE-INDONESIA
DI PROVINSI GORONTALO

Kata antar- merupakan kata terikat yang tidak dapat berdiri sendiri sehingga harus melekat atau ditulis tidak terpisah dengan kata yang diikutinya. Pada kasus ini, kata antar- ditulis dengan huruf kapital dan terikat pada singkatan PPLP. Untuk menghindari kerancuan makna, penulisan yang tepat cukup dengan membubuhkan tanda hubung (-) antara kata antar dan PPLP. Sebaliknya, penulisan bentuk terikat 
se- yang ditulis dengan huruf kapital, tanda hubung tidak perlu digunakan.

Pada Data 25-Gto-40, terdapat kesalahan penggunaan ejaan di penulisan nama Kota Gorontalo, penggunaan tanda elipsis dan tanda seru yang berlebihan. Pada data tersebut, nama Kota Gorontalo ditulis dengan setiap huruf diantarai oleh spasi. Penulisan seperti itu tidak dapat dibaca sebagai sebuah kata, tetapi hanya sebagai kumpulan beberapa huruf. Tanda elipsis pada kalimat Mari Jo...! tidak memiliki makna, sehingga tidak perlu digunakan dalam kalimat tersebut. Demikian halnya tanda seru pada kalimat Ingat!!!, tidak menambah informasi ketegasan seperti yang diinginkan oleh penutur (pemilik iklan). Jadi, penggunaan tanda seru pada kalimat tersebut cukup satu.

\section{Penggunaan bahasa Indonesia pada nama restoran dan kafe}

Dalam kajian ini, terdapat 10 nama restoran dan kafe yang akan dianalisis penggunaan bahasanya, yaituRed Black Restaurant \& Karaoke (25-Gto-41), Hulondalo Indah Sweet Resto (25-Gto-42), Coffee Toffee, Kingdom Foodcourt (25Gto-43), Vanilla Convenient Store, Cake \& Patiserie Supply, One stop shop for all your baking needs (25-Gto-44), Kawan Seafood \& Chinese Food (25-Gto-45), Olivia Resto \& Bakery (25-Gto-46), Domestique (25Gto-47), Pino's Spesial Ikan \& Ayam (25Gto-46), Rasa Seafood All Fresh (25-Gto49), dan 23 Pool Billiard, Karaoke \& Kafe (25-Gto-50).

Pada Data 25-Gto-41, nama Red Black Restaurant \& Karaokedapat dipadankan ke dalam bahasa Indonesia menjadi Restoran dan Karaoke Merah Hitam. Kemudian, pada Data 25-Gto-42, nama Hulondalo Indah Sweet Resto, merupakan campur kode bahasa Gorontalo, bahasa Indonesia, dan bahasa asing. Kata Hulondalo bermakna Gorontalo, kata indah dan resto (kependekan restoran)bahasa Indonesia, dan sweet bahasa Inggris. Nama ini dapat dipadankan menjadi Restoran Nikmat Hulondalo Indah.
Pada Data 25-Gto- 43, nama Coffee Toffeedari segi diksimenggunakan bahasa Inggris, Coffee Toffee. Secara harfiah coffee 'kopi'dan toffee 'karamel', atau dimaknai 'permen cokelat'. Selain kata coffee dan toffee, terdapat kingdom foodcourt. Istilah ini telah dipadankan ke dalam bahasa Indonesia, kingdom 'kerajaan' dan foodcourt 'pusat jajanan; pujasera'.

Pada Data 25-Gto-44, nama Vanilla Convenient Store. Nama toko kue ini telah secara harfiah memiiliki padanan.Kata convenient 'cocok, sesuai, mudah'; 'lapang, luas, besar', kata store 'toko, kedai, warung', cake 'keik, bolu', patisserie 'kue kering' dan kata suply 'pasokan' stok, suplai, persediaan'. Sementara itu kalimat One stop shop for all your baking needs 'tempat berbelanja semua jenis kebutuhan kue Anda'. Dengan demikian, pemilik toko tersebut dapat mengutamakan bahasa Indonesia dengan menggunakan nama Toko Kue Vanila, Stok Kue Bolu dan Kue Kering, Tempat berbelanja semua jenis kue yang Anda butuhkan'.'Tersedia Semua Jenis Kue'.

Pada Data 25-Gto-45, nama Kawan Seafood \& Chinese Food pun telah memiliki padanan kata dalam bahasa Indonesia. Istilah seafood dipadankan dengan boga bahari; hidangan bahari; atau hidangan laut dan Chinese Food 'makanan Cina' atau 'masakan Cina'. Dengan demikian, nama restoran ini dapat diubah menjadi Boga Bahari \& Masakan Cina Ka Wan.

Pada Data 25-Gto-46, nama Olivia Resto \& Bakery dapat dipadankan dengan Restoran dan Toko Roti Olivia atau Restoran dan Toko Kue Olivia.

Pada Data 25-Gto-47, nama Domestique berasal dari bahasa Perancis yang bermakna 'domestik, dalam negeri, keluarga, rumah tangga'.

Pada Data 25-Gto-48, nama Pino's Spesial Ikan dan Ayam menggunakan gabungan bahasa Inggris dan bahasa Indonesia. Nama warung makan ini dapat dipadankan dengan Warung Makan Pino, Spesial Ikan dan Ayam. 
Pada Data, 25-Gto-49, nama Rasa Seafood, All Fresh juga menggunakan gabungan bahasa Inggris dan bahasa Indonesia. Kata seafood dan all fresh sudah memiliki padanan alam bahasa Indonesia. All fresh dapat dimaknai dengan serba segar, semua segar. Dengan demikian, padanan kata nama restoran ini boleh dengan Restoran Rasa Boga Bahari Serba Segar.

Pada Data 25-Gto-50, nama 23 Pool Billiard, Karaoke \& Cafe, menggunakan istilah olahraga biliar, pool 'jenis permainan biliar yang dimainkan oleh di atas meja biliar yang memiliki enam pocket atau kantong bola'. Istilah ini belum memiliki padanan kata dalam bahasa Indonesia. Sementara itu, kata karaoke dipadankan dengan penyerapan secara utuh menjadi karake dan kata cafe telah dipadankan dengan penyesuaian lafal dan ejaan menjadi kafe. Dengan demikian, nama kafe ini boleh saja menggunakan istilah asing dengan syarat dilakukan penyesuaian penulisan dan struktur dalam bahasa Indonesia. Misalnya, $23 \mathrm{Pool}$, Biliar, Karaoke, \& Kafe.

Dengan demikian, beberapa nama tempat usaha ini dapat dipadankan ke dalam bahasa Indonesia. Yang paling utama dilakukan adalah mengubah sikap pemilik usaha agar lebih positif dan tetap setia terhadap bahasa Indonesia.

\section{Penggunaan bahasa Indonesia pada nama pusat perbelanjaan}

Dalam kajian ini terdapat 10 nama pusat perbelanjaan yang akan dianalisis penggunaan bahasanya, yaituMega Zanur Mall (25-Gto-51), Business Park Gorontalo (25-Gto-52), Makro Supermarket \& Dept. Store (25-Gto-53), Swalayan Jayamart (25Gto-54), Plaza Listrik (25-Gto-55), Qmart Superstore (25-Gto-56), Santika Supermarket Furniture (25-Gto-57), Divana Mart (25-Gto-58), Aisyah Mart (25-Gto59), dan Mall Karsa Utama(25-Gto-60).

Berdasarkan data di atas, diketahui bahwa nama pusat perbelanjaan di Kota Gorontalo pada umumnya menggunakan bahasa asing dengan konsep yang berbedabeda. Kata yang digunakan adalah mall, plaza, supermarket,superstore, dan mart. Selain itu, terdapat pula pencampuradukan struktur bahasa asing dan bahasa Indonesia. Adapun data yang menggunakan kata mall dapat dilihat pada Data 25-Gto51, Mega Zanur Mall, dan Data 25-Gto-60, Mall Karsa Utama. Dari segi diksi, kata mall telah diserap ke dalam bahasa Indonesia dengan penyesuaian ejaan, yaitu mal. Kata mal bermakna gedung atau kelompok gedung yang berisi macammacam toko dihubungkan oleh lorong (jalan penghubung).

Dari segi struktur, Data 25-Gto-51 menggunakan struktur bahasa Inggris dan Data 25-Gto-60 menggunakan struktur bahasa Indonesia. Oleh karena itu, nama kedua pusat perbelanjaan ini perlu diperbaiki menjadi Mal Mega Zanur dan Mal Karsa Utama.

Data yang menggunakan kata plaza adalah Data 25-Gto-55. Dari segi diksi, kata plaza sudah diserap secara utuh ke dalam bahasa Indonesia. Kata ini bermakna pusat pertokoan dengan tempat parkir. Dari segi struktur, nama ini sudah sesuai dengan struktur bahasa Indonesia, diterangkan dan menerangkan.

Data yang menggunakan kata mart ada empat, yaitu Data 25-Gto-54, Swalayan Jayamart; Data 25-Gto-56, Qmart Super Store; Data 25-Gto-58, Diana Mart; danData 25-Gto-59, Aisyah Mart. Dari segi diksi, istilah mart telah dipadankan ke dalam bahasa Indonesia 'toko, kios'. Dengan demikian, nama pusat perbelanjaan tersebut dapat diganti dengan Toko Swalayan Jaya, Toko Diana, dan Toko Aisyah. Sementara itu, nama Qmart Super Store menggunakan kata mart dan superstore, 'toko'dan 'toko raya' dengan sebuah konsep toko besar. Pemilik toko dapat memilih opsi lain dengan Toko Raya $Q$.

Data yang menggunakan kata supermarket ada dua, yaitu Data 25-Gto-53, Makro Supermarket \& Departemen Store, dan Data 25-Gto-57, Santika Supermarket 
\&Furniture. Istilah supermarket juga telah dipadankan ke dalam bahasa Indonesia melalui penerjemahan yaitu pasar swalayan. Demikian halnya dengan istilah departemen store telah dipadankan dengan penerjemahan yaitu pasaraya atau toko serba ada (toserba) dan furniture telahdipadankan dengan menyesuaikan ejaannya yaitu furnitur. Oleh karena itu, nama yang tepat kedua pusat perbelanjaan ini dalam bahasa Indonesia Pasar Swalayan dan Toserba Makro atau Pasar Swalayan dan Pasaraya Makro, Pasaraya \& Furnitur Santika atau Toserba \& Furnitur Santika.

Selanjutnya, masih terdapat satu data pusat perbelanjaan yang menggunakan bahasa asing yaitu Data 25-Gto-52, Business Park Gorontalo, yang menggunakan struktur bahasa Indonesia tetapi berbahasa Inggris. Nama tempat bisnis ini dapat dipadankan dengan Taman Bisnis Gorontalo.

\section{Penggunaan bahasa Indonesia pada nama instansi pemerintah \\ Dalam kajian ini terdapat 10 nama} instansi pemerintah yang akan dianalisis penggunaan bahasanya, yaitu Badan Pertanahan Nasional Kota Gorontalo (25Gto-61), Unit Pelaksana Teknis Dinas Pelabuhan Perikanan Tenda dan Pelayanan Usaha (25-Gto-62), BKPPD Provinsi Gorontalo (25-Gto-63), Bappeda Provinsi Gorontalo (25-Gto-64), Pusat Pelayan Autis (25-Gto-65), Kantor Camata Kota Utara (25-Gto-66), Polri Daerah Gorontalo Resor Kota Gorontalo Sektor Kota Utara (25-Gto67), Kantor Kelurahan Limba 2(25-Gto68), Dewan Perwakilan Rakyat Daerah Kota Gorontalo (25-Gto-69), dan Badan Keuangan Kota Gorontalo (25-Gto-70).

Berdasarkan informasi Tabel 5 diketahui bahwa pada umumnya masalah kebahasaan yang perlu diperbaiki pada penulisan nama dan alamat instansi pemerintah adalah penggunaan tanda koma pada alamat instansi, kesalahan penulisan kata, penulisan singkatann, dan penggunaan istilah asing pada alamat kantor, serta kesalahan pilihan kata.

Data yang berkaitan dengan kesalahan penggunaan tanda koma terdapat pada Data 25-Gto-61, 25-Gto-64, 25-Gto65, 25-Gto-66, 25-Gto-67, 25-Gto-68 yang tidak mematuhi kaidah penggunaan tanda koma di antara nama dan alamat serta bagian-bagian alamat.

Sementara itu, penulisan kata yang tidak tepat terdapat pada penulisan pada nama tempat yang memiliki spasi antarhuruf seperti dalam Data 25-Gto-69, K o t a G o r o n t a 1 o, untuk memenuhi ruang penulisan. Penulisan seperti ini tidak dibenarkan karena yang ditulis tidak dapat dibaca sebagai sebuah kata.

Adapun bahasa asing yang digunakan pada alamat instansi adalah kata fax dan by-pass. Dalam data ini, kata faximile disingkat dengan fax.Faximile telah dipadankan ke dalam bahasa Indonesia dengan menyesuaikan ejaannya, faksimile, sehingga jika akan disingkat menjadi faks. bukan fax. Selanjutnya, kata by-pass pun telah dipadankan melalui penerjemahan, jalan bentar; jalan lingkar.

Oleh karena itu, penulisan alamat yang tepat dapat dilihat pada perbaikan salah satu data berikut ini.

Data 25-Gto-61, Jln. P. Kalengkongan No. 18, Kota Gorontalo, Telp./Faks. 0435-821013

Terakhir, pada Data 25-Gto-68, terdapat kesalahan pilihan kata yaitu kelurahan. Kata ini bermakna kantor (rumah) lurah. Dengan demikian, jika digunakan dalam sebuah nama tempat seperti Kantor Kelurahan Limba, maknanya menjadi ambigu. Diksi yang tepat untuk frasa tersebut adalah Kantor LurahLimba.

\section{Penggunaan bahasa Indonesia pada nama warung makan}

Dalam kajian ini terdapat 10 nama warung makan yang akan dianalisis penggunaan bahasanya, yaitu RM. Bang Rofiq (25-Gto-71), RM. Jalangkote Manalagi (25-Gto-72), Holchik Factory 
(25-Gto-73), Rumah Makan "Ohara” (25Gto-74), Waroeng Coffee Simpang Lima (25-Gto-75), Waroenk Narcoffee (25-Gto76), Rumah Makan \&Cafe "R-3"(25-Gto77), Cafe \& R.M "Sederhana" Mas Adji (25-Gto-78), RM Semanan New (25-Gto79), dan Waroeng Spensa (25-Gto-60)

Berdasarkan data tersebut, diketahui bahwa penulisan nama rumah makan di Kota Gorontalo bermacam-macam, yaitu penggunaan tanda titik pada singkatan yang bukan nama diri, penggunaan tanda petik pada nama diri, penggunaan bahasa asing, penggunaan diksi yang salah, dan penggunaan ejaan lama.

Adapun data yang menggunakan tanda titik pada singkatan yang bukan nama diri yaitu Data 25-Gto-71, RM. Bang Rofiq, dan 25-Gto-72, R.M. Jalangkote Manalagi. Dalam kaidah ejaan, singkatan yang bukan nama diri ditulis dengan huruf kapital tanpa tanda titik. Oleh karena itu, nama kedua rumah makan ini seharusnya ditulis dengan RM Bang Rofiq dan RM Jalangkote Manalagi.

Selanjutnya, data yang menggunakan tanda petik ganda pada nama diri yaitu Data 25-Gto-74, 25-Gto-77, dan 25-Gto-78. Dalam kaidah ejaan, tanda petik ganda tidak digunakan untuk mengapit sebuah nama. Selain itu, dari segi diksi, kata cafe telah diserap ke dalam bahasa Indonesia dengan penyesuaian ejaan, kafe. Dengan demikian, tanda petik pada nama rumah makan tersebut harus dihilangkan, dan kata cafediganti dengan kafe, Rumah Makan Ohara, Rumah Makan \& Kafe R-3, dan Kafe \& RM Sederhana Mas Adji.

Data yang menggunakan bahasa asing yaitu Data 25-Gto-73, 25-Gto-75, dan 25-Gto-79. Data 25-Gto-73, Holchick Factory merupakan nama sebuah usaha waralaba. Holchick merupakan singkatan dari Holland Chicken 'ayam Belanda', 'masakan ayamdengan resep dari Belanda', dan factory bermakna pabrik. Lam Bahasa asing yang terdapat pada Data 25-Gto-75 adalah kata coffee. Kata ini digunakan dengan menggabungkaannya dengan kata dalam bahasa Indonesia, Waroeng Coffee Simpang Lima 'Warung Kopi yang terletak di Simpang Lima'. Sementara itu, Data 25Gto-79, RM Semanan New, dengan struktur bahasa Indonesia. Seharusnya, kata new diganti dengan baru, RM Semanan Baru.

Selanjutnya, terdapat satu data yang menggunakan diksi yang salah, yaitu pada Data 25-Gto-76, Warunk Narcoffee. Dalam bahasa Indonesia, tidak terdapat kata warunk, yang benar adalah warung. Demikian halnya dengan kata narcoffee, tidak memiliki arti dalam bahasa Indonesia.Kata ini dimaknai pecandu kopi oleh pemiliknya, karena kata selanjutnya pada nama warung ini adalah komunitas pecandu kopi.

Terakhir, penggunaan ejaan lama bunyi [oe] pada Data 25-Gto-75 dan 25Gto-80, Waroeng Coffee Simpang Lima dan Waroeng Spensa.

\section{Penggunaan bahasa Indonesia pada nama PT dan CV}

Dalam kajian ini terdapat 10 nama PT dan CV yang akan dianalisis penggunaan bahasanya, yaitu CV. Endai Lestari (25Gto-81), PT. Azwa Utama (25-Gto-82), CV. Kemalindo Utama (25-Gto-83), CV. Bahtera Sulawesi Dieselindo (25-Gto-84), CV. Andri Jaya Computer (25-Gto-85), PT. Pertamina (25-Gto-86), PT. Penjaminan Jamkrindo Syariah (25-Gto-87), PT. Semeru Teknindo Lestari (25-Gto-86), PT. Togo Jaya (25-Gto-89), dan PT. Perikanan Nusantara Perwakilan Gorontalo (25-Gto90),

Berdasarkan data nama PT dan CV tersebut, diketahui bahwa semua data PT dan CV di Kota Gorontalo ditulis dengan menggunakan tanda titik, padahal PT dan $\mathrm{CV}$ termasuk singkatan bukan nama diri yang tidak ditandai dengan tanda titik. Oleh karena itu, penulisan PT dan CV pada semua data tersebut perlu disesuaikan dengan kaidah ejaan. Misalnya, CV Endai Lestari, PT Azwa Utama. 


\section{Penggunaan bahasa Indonesia pada nama toko pakaian \\ Dalam kajian ini terdapat 10 nama} toko pakaian yang akan dianalisis penggunaan bahasanya, yaitu Indah Batik (25-Gto-91), Billy Collection Jakarta (25Gto-92), Rafa Style Distro \& Fashion Accessories (25-Gto-93), Bee Shop Gorontalo (25-Gto-94), Denia Fashion (25Gto-95), Asyifa Fashion (25-Gto-96), Nandhira Fashion (25-Gto-97), Madinah Baru (25-Gto-98), Jakarta fashion (25-Gto99), dan Junior Clothing (25-Gto-100).

Berdasarkan data nama toko pakaian tersebut, diketahui bahwa pada umumnya nama toko pakaian di Kota Gorontalo menggunakan bahasa asing. Hanya dua data yang mnggunakan bahasa Indonesia yaitu Data 25-Gto-98, Madinah Baru, dan Data 25-Gto-91, Indah Batik. Akan tetapi, Data 25-Gto-91 menggunakan struktur bahasa asing, yang seharusnya Batik Indah.

Data 25-Gto-92 menggunakan istilah colection [collection]. Istilah ini telah dipadankan ke dalam bahasa Indonesia melalui penyesuaian ejaan dan lafal menjadi koleksi. Dari segi struktur, nama toko ini perlu pula disesuaikan dengan struktur bahasa Indonesia, Koleksi Jakarta Billy di Kota Gorontalo.

Data 25-Gto-93 menggunakan istilah style, distro, fashion, dan accessories. Kata style telah dipadankan melalui penerjemahan, gaya. Istilah distro merupakan singkatan dari distribution store 'toko distributor'. Kata ini telah diserap ke dalam bahasa Indonesia.Kata fashion dipadankandengan pakaian, busana, mode. Kata accessories dipadankan dengan aksesori. Dengan demikian, nama toko ini dapat diindonesiakan dengan Gaya Rafa, Distro \&Busana, Aksesori.

Selain Data 25-Gto-91, terdapat data lainnya yang menggunakan fashion, yaitu Data 25-Gto-95, Data 25-Gto-96, Data 25-Gto-97, Data 25-Gto-99. Oleh karena itu, semua nama tersebut dapat diindonesiakan, misalnya Busana Denia, Busana Asyifa, Busana Nandhira, dan Busana Jakarta.

Data 25-Gto-94 mengunakan frasa bee shop sebagai nama toko. Kata bee bermakna lebah dan kata shop bermakna gerai, toko. Toko ini selalin menjual madu, juga menjual pakaian. Dengan demikian, nama toko ini dapat diindonesiakan dengan Toko Lebah Gorontalo, Gerai Madu Gorontalo.

Data terakhir, Data 25-Gto-100 menggunakan frasa junior clothing. Kata junior bermakna junior, kecil, anak kecil dan kata clothing bermakna pakaian atau busana. Dengan demikian, nama toko ini juga dapat diindonesiakan dengan Busana Anak, Busana kecil, Busana Junior.

\section{Aspek Fisik Kebahasaan pada Ruang Publik Kota Gorontalo}

Berdasarkan aspek fisik kebahasaan, hampir setengah data dalam kajian ini mengutamakan bahasa negara, dan lebih dari setengahnya tidak mengutamakan bahasa negara.Grafik 5 berikut menegaskan kondisi tersebut. 


\section{Grafik 5. Aspek Fisik Kebahasaan}

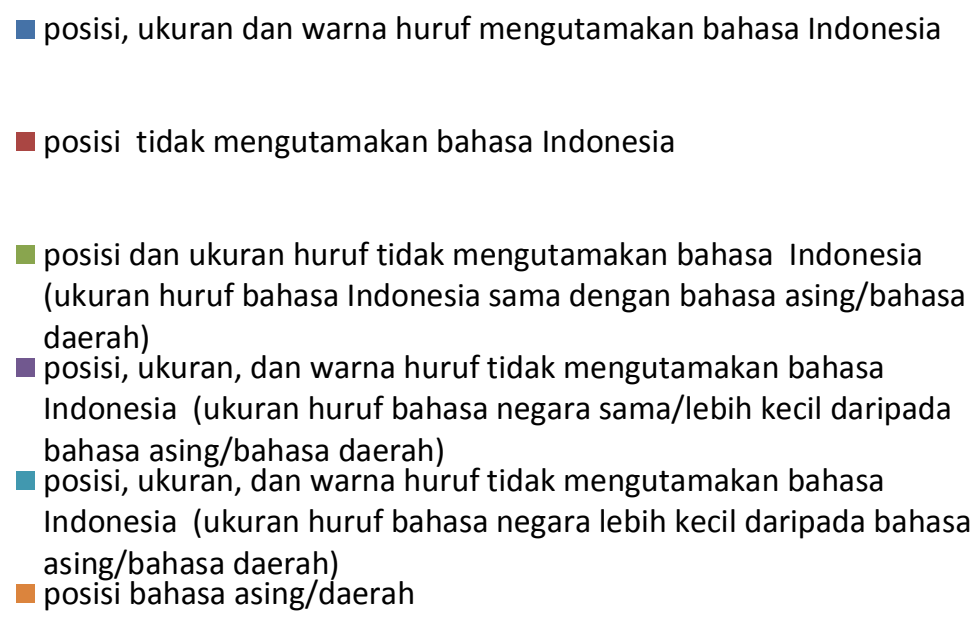

Dalam Grafik 5 di atas, dijelaskan bahwa data aspek fisik kebahasaan (posisi, ukuran huruf, dan warna huruf), yang telah mengutamakan bahasa Indonesia sebanyak 34 data atau hanya 34\%. Sementara itu, terdapat $5 \%$ data yang menempatkan bahasa negara di atas/di bawah/berdampingan dengan bahasa asing dan/atau bahasa tak resmi, 2\% data menempatkan bahasa negara di atas/di bawah/ berdampingan dengan bahasa asing dan/atau bahasa tak resmi serta membuat ukuran huruf bahasa negara sama dengan bahasa asing dan/atau bahasa tak resmi (kedaerahan). Kemudian, sebanyak 15\% data yang menempatkan bahasa negara di atas/di bawah/ berdampingan dengan bahasa asing dan/atau bahasa tak resmi, membuat ukuran huruf bahasa negara sama dengan bahasa asing dan/atau bahasa tak resmi (kedaerahan), dan membuat warna huruf bahasa negara sama dengan bahasa asing dan/atau bahasa tak resmi (kedaerahan). Sebanyak 3\% data yang menempatkan bahasa negara di atas/di bawah/ berdampingan dengan bahasa asing dan/atau bahasa tak resmi, membuat ukuran huruf bahasa negara sama lebih kecil daripada bahasa asing dan/atau bahasa tak resmi (kedaerahan); hanya menggunakan bahasa asing dan/atau bahasa tak resmi (kedaerahan) dalam ukuran apa pun, dan membuat warna huruf bahasa negara sama dengan bahasa asing dan/atau bahasa tak resmi (kedaerahan). Terakhir, terdapat $41 \%$ data yang posisinya hanya menempatkan bahasa asing dan/atau bahasa tak resmi (kedaerahan), ukuran hurufnya bahasa negara sama lebih kecil daripada bahasa asing dan/atau bahasa tak resmi (kedaerahan); hanya menggunakan bahasa asing dan/atau bahasa tak resmi (kedaerahan) dalam ukuran apa pun, serta membuat warna bahasa asing lebih mencolok daripada bahasa negara atau hanya menggunakan bahasa asing dan/atau bahasa tak resmi (kedaerahan).

\section{Aspek Tipografi Kebahasaan pada Ruang Publik di Kota Gorontalo}

Berdasarkan tipografi kebahasaan, lebih dari setengah data kajian ini mengutamakan bahasa negara/bahasa Indonesia. Hal tersebut tergambar pada Grafik 3 berikut. 


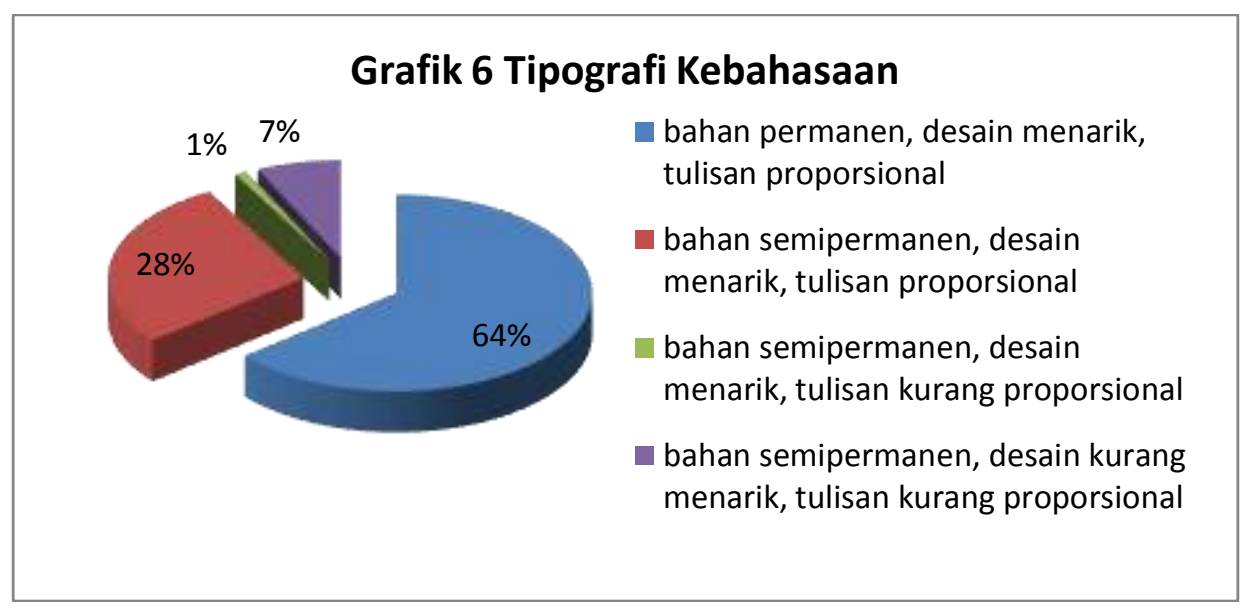

Berdasarkah Grafik 6 di atas, terdapat $64 \%$ data yang terbuat dari bahan permanen (kayu, batu, kaca atau kaca serta), desain yang menarik, dan tulisannya sangat jelas serta proporsional. Sebanyak $28 \%$ data yang terbuat dari bahan semipermanen (plastik, kain, atau styrofoam), desain yang menarik, dan tulisannya sangat jelas serta proporsional.Terakhir, terdapat $1 \%$ data yang bahannya semipermanen, desain yang menarik, dan tulisannya kurang jelas serta kurang proporsional, dan $7 \%$ data yang bahannya semipermanen, desain kurang menarik dan tulisan kurang jelas serta kurang proporsional.

\section{Tingkat Keterkendalian Penggunaan Bahasa Indonesia di Ruang Publik Kota Gorontalo}

Dalam kajian ini ditemukan bahwa keterkendalian Penggunaan Bahasa Indonesia pada Ruang Publik di Kota Gorontalo berada pada kategori Terkendali $C$ (dengan jumlah nilai 2090), yang bermakna bahwa Kategori ini menunjukkan wilayah yang penggunaan bahasa di ruang publiknya kurang terkendali: secara fisik kurang didominasi bahasa asing; mulai lebih banyak berbahasa negara dengan penerapan kaidah dan tipografi yang mulai baik.Jumlah nilai keterkendalian tersebut diperoleh dari hasil perjumlah nilai bobot aspek kaidah kebahasaan, aspel fisik kebahasaan, dan aspek tipografi kebahasaan.
Penggunaan bahasa asing di ruang publik tidak terjadi dengan sendirinya. Akan tetapi, didorong oleh nilai prestisius yang dirasakan oleh masyarakat bahwa nilai jual produk barang dan jasa mereka lebih tinggi jika menggunakan bahasa asing dibandingkan jika menggunakan bahasa Indonesia. Hal tersebut menunjukkan bahwa masyarakat masih bersikap negatif terhadap bahasa negara.Dalam hal ini pula, peran dan andil pemerintah dalam melakukan pengendalian secara terstruktur sangat menentukan keterkendalian bahasa ruang publik. Masalah kebahasaan belum menjadi perioritas pemerintah dalam memberikan izin usaha.

\section{PENUTUP}

Berdasarkan hasil analisis dan
pembahasan di atas disimpulkan bahwapenggunaan bahasa Indonesia pada ruang publik di Kota Gorontalo belum terkendali dengan baik karena masih berada di kategori Terkendali $C$, yang menunjukkan bahwa wilayah penggunaan bahasa Indonesia di ruang publik Kota Gorontalo kurang terkendali: secara fisik kurang didominasi bahasa asing; mulai lebih banyak berbahasa negara dengan penerapan kaidah dan tipografi yang mulai baik. Berikut ini rinciannya.

1. Dari aspek kebahasaan, hanya 8 data $(8 \%)$ yang mengutamakan penggunaan bahasa Indonesia. Selebihnya, $92 \%$ terdapat masalah pada ejaan, pilihan kata, dan struktur kalimat. 
2. Dari aspek fisik kebahasaan $34 \%$ data yang telah mengutamakan bahasa Indonesia dan $66 \%$ yang tidak mengutamakan bahasa Indonesia dengan membuat posisi bahasa Indonesia sejajar/di bawah/ di atas/di samping bahasa asing atau bahasa daerah, ukuran huruf yang bahasa asing/bahasa daerah lebih besar/lebih jelas daripada ukuran huruf bahasa Indonesia.

3. Berdasarkah aspek tifografi kebahasaannya, terdapat $64 \%$ data yang terbuat dari bahan permanen, desain yang menarik, dan tulisannya sangat jelas serta proporsional, $28 \%$ data yang terbuat dari bahan semipermanen, desain yang menarik, dan tulisannya sangat jelas serta proporsional, $1 \%$ data yang bahannya semipermanen, desain yang menarik, dan tulisannya kurang jelas serta kurang proporsional, dan $7 \%$ data yang bahannya semipermanen, desain kurang menarik dan tulisan kurang jelas serta kurang proporsional.

Sekaitan dengan itu, secara umum bentuk kesalahan yang terdapat pada Penggunaan bahasa Indonesia di ruang publik Kota Gorontalo sebagai berikut.

1. Dari segi ejaan, terkait dengan pengunaan tanda titik pada singkatan pada gelar, singkatan bukan nama diri, singkatan lambang mata uang; tanda koma

\section{DAFTAR PUSTAKA}

Hasanuddin, Cahyo. 2017. “Analisis Kesalahan Berbahasa pada Penulisan Media Luar Ruang di Kabupaten Bojonegoro". Online (http://ejournal.upi.edu/index.php/ BS_JPBSP/article/view/6963)

Diakses pada tanggal 29 Januari 2018.

Kurniawati, Wati. 2015. "Olah Kata dalam Media Luar Ruang sebagai Industri Kreatif'. Ranah. Jurnal pada alamat, pada rincian; tanda hubung pada kata terikat, tanda petik ganda pada nama diri, tanda elipsis, tanda pisah, tanda garis miring, penulisan kata depan $d i$, dan penulisan kata tidak serangkai.

2. Dari segi diksi atau pilihan kata, data kajian ini memberdayakan kata dan istilah asing yang telah memiliki padanan kata dalam bahasa Indonesia, menggunakan bentuk kata yang tidak baku, mencampuradukkan antara bahasa Indonesia dan bahasa asing, menggunakan bentuk kata yang tidak benar, dan menggunakan pilihan kata yang tidak tepat.

3. Dari segi struktur, terdapat beberapa data yang menggunakan bahasa Indonesia dengan struktur bahasa asing.

Berdasarkan pembahasan dan simpulan di atas, penulis menyarankan agar

1. Pemerintah atau pihak yang terkait perlu mengambil kebijakan untuk memartabatkan bahasa Indonesia di ruang publik dan melakukan penertiban penggunaan bahasa Indonesia di ruang publik .

2. Badan Pengembangan dan Pembinaan Bahasa beserta balai dan kantor bahasa di seluruh Indonesia semakin giat menyosialisasikan pengutamaan bahasa Indonesia pada ruang publik.

Bajian Bahasa. Volume 4, Nomor 2, Desember 2015. ISSN 23388528. Jakarta: Badan Pengembangan dan Pembinaan Bahasa.

Nurkumala, Ercita Intan, dkk. 2015. "Penggunaan Bahasa pada Penulisan Media Luar Ruang di Kota Ketapang". Online (http://jurnal.untan.ac.id/index.ph p/jpdpb/article/view/20877) dan (https://media.neliti.com/media/pu $\underline{\mathrm{b}}$ 
lications/211388-penggunaan-bahasapada-penulisan-media-l.pdf) Diakses pada tanggal 29 Januari 2018.

Purba, Amran dan Suyadi. "Bahasa di Ruang Publik, Indonesia vs Asing". Kolofon. Edisi Nomor 1, Volume 1,

Maret 2016. Majalah Buletin Bahasa. Medan: Balai Bahasa Sumatera Utara.

Rosadi, Moh., 2017. "Penggunaan Ejaan pada Media Luar Ruang di Kabupaten Gorontalo Utara”. Laporan Kajian. Gorontalo: Tanpa Penerbit.

Tim Penyusun. 2012. Pengindonesiaan Kata dan Ungkapan Asing. Jakarta: Badan Pengembangan dan Pembinaan Bahasa Kementerian Pendidikan dan Kebudayaan.

Tim Penyusun Undang-Undang, 2011. Undang-Undang Republik Indonesia Nomor 24 Tahun 2009. Badan Pengembangandan Pembinaan Bahasa. Kementerian Pendidikan dan Kebudayaan.

Tim Penyusun, 2018. Petunjuk Teknis Pengutamaan Penggunaan Bahasa Negara di Ruang Publik Tahun 2018. Badan Pengembangan dan Pembinaan Bahasa, Kementerian Pendidikan dan Kebudayaan. 